\title{
Mitochondria in the midgut epithelial cells of sugarcane borer parasitized by Cotesia flavipes (Cameron, 1891)
}

\author{
Pinheiro, DO.*, Silva, MD. and Gregório, EA. \\ Departamento de Morfologia, Instituto de Biociências, Universidade Estadual Paulista - UNESP, \\ Rubião Júnior, s/n, CEP 18618-000, Botucatu, SP, Brazil \\ *e-mail: daniela_pinheiro@yahoo.com \\ Received July 28, 2008 - Accepted August 27, 2008 - Distributed February 28, 2010
}

(With 3 figures)

\begin{abstract}
The sugarcane borer Diatraea saccharalis (Lepidoptera: Crambidae) has been controlled by Cotesia flavipes (Hymenoptera: Braconidae); however, very little is known about the effect of the parasitism in the host organs, including the midgut. This work aims to verify mitochondrial alteration in the different midgut epithelial cells of D. saccharalis parasitized by C. flavipes. Midgut fragments (anterior and posterior region) of both non-parasitized and parasitized larvae were processed for transmission electron microscopy. The mitochondria of midgut epithelial cell in the parasitized larvae exhibit morphological alteration, represented by matrix rarefaction and vacuolisation. These mitochondrial alterations are more pronounced in the anterior midgut region during the parasitism process, mainly in the columnar cell.
\end{abstract}

Keywords: midgut, Diatraea saccharalis, mitochondria, Cotesia flavipes, epithelial cell.

\section{Mitocôndria nas Células Epiteliais do Intestino Médio da Broca-da-cana Parasitada por Cotesia flavipes}

\begin{abstract}
Resumo
Diatraea saccharalis (Lepidoptera: Crambidae), broca da cana-de-açúcar, tem sido controlada por Cotesia flavipes (Hymenoptera: Braconidae); pouco se sabe sobre o efeito do parasitismo nos diferentes órgãos do inseto hospedeiro, principalmente no intestino médio. O objetivo desse trabalho foi verificar as alterações mitocondriais das diferentes células epiteliais do intestino médio de larvas de $D$. saccharalis parasitadas por $C$. flavipes. Fragmentos do intestino médio (regiões anterior e posterior) de larvas de $D$. saccharalis não-parasitadas e parasitadas foram processados para microscopia eletrônica de transmissão. As mitocôndrias das células epiteliais do intestino médio de larvas parasitadas exibem alterações, especialmente rarefação e vacuolização da matriz, que foram mais pronunciadas nas células epiteliais da região anterior do intestino médio na vigência do parasitismo, em especial nas células colunares.
\end{abstract}

Palavras-chave: intestino médio, Diatraea saccharalis, mitocôndria, Cotesia flavipes, célula epitelial.

\section{Introduction}

Diatraea saccharalis (Fabricius, 1794) (Lepidoptera: Crambidae), serious pests in sugarcane culture, has been controlled by Cotesia flavipes (Cameron, 1891). (Hymenoptera: Braconidae). The midgut of Lepidoptera larvae is morphologically differentiated throughout its length (Santos et al., 1984; Jordão et al., 1999; Pinheiro and Gregório, 2003; Pinheiro et al., 2003, 2008a, b; Levy et al., 2004); its epithelium is composed of 4 cell types: columnar, goblet, regenerative and endocrine (Lehane and Billingsley, 1996).

There is much research that has shown the importance and distribution of mitochondria in the midgut epithelial cells of insects (Mandel et al., 1980; Baker et al., 1984; Hung et al., 2000; Serrão and Cruz-Landim, 2000; Clark et al., 2005). It is known that the mitochondria present in the apical portion of columnar cells are involved in the absorption and metabolism of nutrients, while in the basal portion of columnar cells, this organelle is related to the nutrient and ion transport from the cell to the hemolymph (Lehane and Billingsley, 1996; Hung et al., 2000). The mitochondria present in the microvilli of the goblet cell cavity would be related to active transport mechanisms of $\mathrm{K}^{+}$ions, realised by these cells (Anderson and Harvey, 1966; Harvey et al., 1983; Moffett et al., 1995). 
Most studies on the effect of parasitism in Lepidoptera larvae approach alterations in development, reproduction, behaviour and hormonal levels of insects (for a review see Edwards and Weaver, 2001), with little emphasis on morphological modifications, including ultrastructural ones, in different organs of the host insect.

This work aims to verify the effect of $C$. flavipes in mitochondria of epithelial midgut cells in D. saccharalis larvae, and whether the eventual alterations in mitochondria may be related to the localisation of the epithelial cell along the midgut length.

\section{Material and Methods}

The insects were reared on an artificial diet and maintained under controlled conditions $\left(26 \pm 1{ }^{\circ} \mathrm{C} ; 70 \pm 5 \%\right.$ relative humidity and 14:10 L:D). Cotesia flavipes females were allowed to oviposit on the dorsal surface of last instar Diatraea saccharalis larvae (15-18 days of development); the parasitized and non-parasitized (control) larvae were sampled at 6 days after parasitism. Both non-parasitized and parasitized larvae were dissected in plate of petri; the midgut was removed and fragmented in the anterior and posterior regions. The midgut fragments were transferred to $2.5 \%$ glutaraldehyde $+4 \%$ paraformaldehyde fixative solution in $0.1 \mathrm{M}$ sodium phosphate buffer ( $\mathrm{pH} \mathrm{7.3)} \mathrm{for} 24$ hours, post-fixed in $1 \%$ osmium tetroxide in the same buffer for 2 hours, dehydrated in a graded acetone series and embedded in Araldite ${ }^{\circledast}$ resin. Ultrathin sections were double-stained with uranyl acetate and lead citrate and examined under a Philips CM100 transmission electron microscope. The mitochondrial morphometric analysis was not realised; the analysis to quantify the mitochondria is obtained by morphological parameters, so it could not present significantly different dates.

\section{Results}

Both parasitized and non-parasitized larvae present the four types of midgut epithelial cells previously reported for caterpillars.

- Columnar cells: in non-parasitized larvae, the mitochondria have highly electron-dense matrix and many cristae (Figures 1a-e), and are abundant in the base of columnar cells of the anterior midgut region (Figure 1b); in the posterior midgut region, the mitochondria are concentrated in the apical cytoplasm (Figure 1c). In parasitized larvae, the mitochondria increase in quantity in both midgut regions, the majority of them presenting few cristae and lower electron dense matrix (Figures 1f-k) than in non-parasitized larvae. These mitochondria were shown to be more altered in the cells of the anterior midgut region, presenting matrix rarefaction (Figures $1 \mathrm{f}, \mathrm{h}$ ) and vacuolisation (Figures 1g,i) of the mitochondrial matrix, under the effect of parasitism.
- Goblet cells: in non-parasitized larvae, the mitochondria are concentrated inside the microvilli, present in the basolateral region of the goblet cell cavity, where the mitochondria have highly electron-dense matrix and many cristae, as much in goblet cells of the anterior region as in the posterior midgut region (Figures $2 a-b$ ). The parasitized larvae present mitochondrial alteration in the basolateral portion of these cells in the two midgut regions, represented by rarefaction (Figures 2c-e) and vacuolisation (Figures $2 \mathrm{f}-\mathrm{g}$ ) of the mitochondrial matrix, alterations that affect a greater number of mitochondria in the anterior midgut region (Figures 2c-f).

- Regenerative cells: in non-parasitized larvae, the distribution, number and morphology of their scarce mitochondria do not present variation in regenerative cells of the anterior and posterior midgut regions (Figure 3a). In parasitized larvae, the mitochondria are more abundant (Figure $3 b$ ) presenting discrete matrix rarefaction (Figure 3c), and reducing the quantity of cristae and mitochondrial vacuolisation in those of the anterior midgut region (Figure 3c), but do not show alteration in the posterior region (Figure $3 \mathrm{~d}$ ).

- Endocrine cells: in non-parasitized larvae, the distribution, number and morphology of their mitochondria do not present variation in the anterior and posterior midgut regions (Figure 3e). The mitochondria of endocrine cells show variability in the quantity of cristae and matrix electron density in the anterior midgut region (Figures $3 \mathrm{f}-\mathrm{h}$ ). In the parasitized larvae we observed matrix rarefaction only in the anterior midgut region (Figures 3f-g).

The characteristics and mitochondrial modifications of the epithelial cells in D. saccharalis, non-parasitized larvae and those parasitized by $C$. flavipes along the midgut length, are summarised in Table 1.

\section{Discussion}

The mitochondria of midgut epithelial cells present ultrastructural alterations along the midgut length of D. saccharalis larvae due to parasitism by $C$. flavipes; the epithelial cells are being affected by parasitism in a different manner, depending on the midgut region.

The columnar cells, especially in the anterior midgut region, are considered responsible for digestive enzymes and peritrophic membrane secretions, besides acting in the absorption of final digestion products (Santos et al., 1984; Lehane and Billingsley, 1996; Jordão et al., 1999). Many studies show that the digestion process along the midgut is dependent on various digestive enzymes, whose production by columnar cells is variable throughout the midgut length. In Tenebrio molitor Linnaeus, 1758 (Coleoptera, Tenebrionidae), most of the enzymes are produced by columnar cells of the anterior midgut region, where 

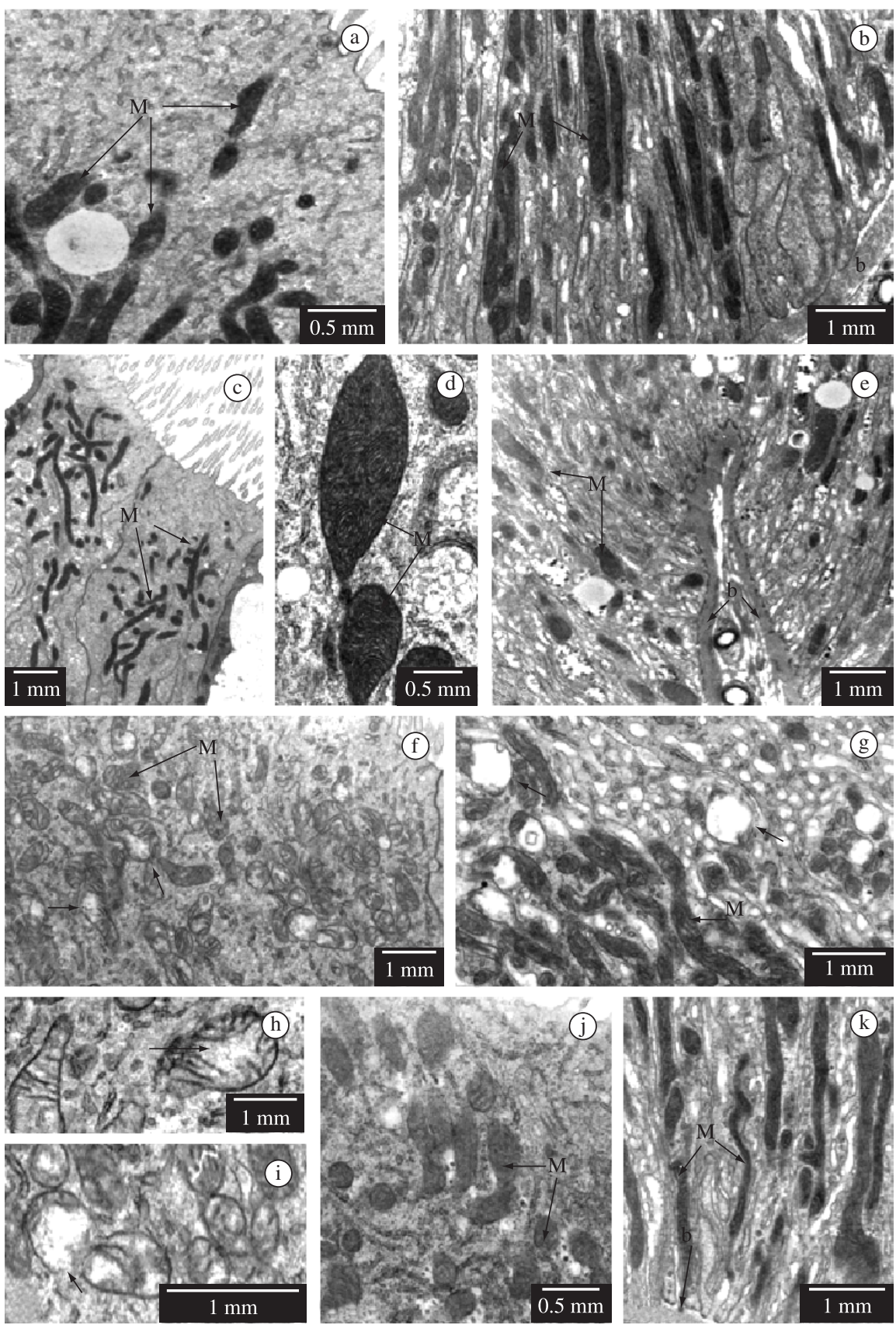

Figure 1. Columnar cell in Diatraea saccharalis larvae, non-parasitized (a-e) and parasitized by Cotesia flavipes (f-k). Mitochondria (M); midgut lumen (L); basal lamina (b); a) Apical cytoplasm - anterior region; b)- Basal cytoplasm - anterior region; c) Apical cytoplasm - posterior region. Goblet cell cavity (*); d) Apical cytoplasm - posterior region; e) Basal cytoplasm - posterior region; f) Apical cytoplasm - anterior region. Matrix rarefaction (arrow); g) Basal cytoplasm- anterior region. Vacuolisation of mitochondrial matrix (arrow); h) Detail of matrix rarefaction (arrow); i) Detail of vacuolisation (arrow) of matrix; and j) Apical cytoplasm.

they appear in larger quantity and present greater activity (Ferreira et al., 1990); a greater secretion of amylase and trypsin by columnar cells of the anterior midgut region was observed in Spodoptera frugiperda (Smith, 1797) (Lepidoptera, Noctuidae) (Jordão et al., 1999) and Erinnys ello Linnaeus, 1758 (Lepidoptera, Sphingidae) (Santos et al., 1984). Digestive enzymes would be secreted to the lumen in the anterior midgut region and directed to the posterior region; the partially directed food and digestive enzymes crossed the peritrophic membrane and, in the ectoperitrophic space, would follow the countercurrent water flow, and are directed again to the anterior midgut region, where final digestion and absorption of food occur on 

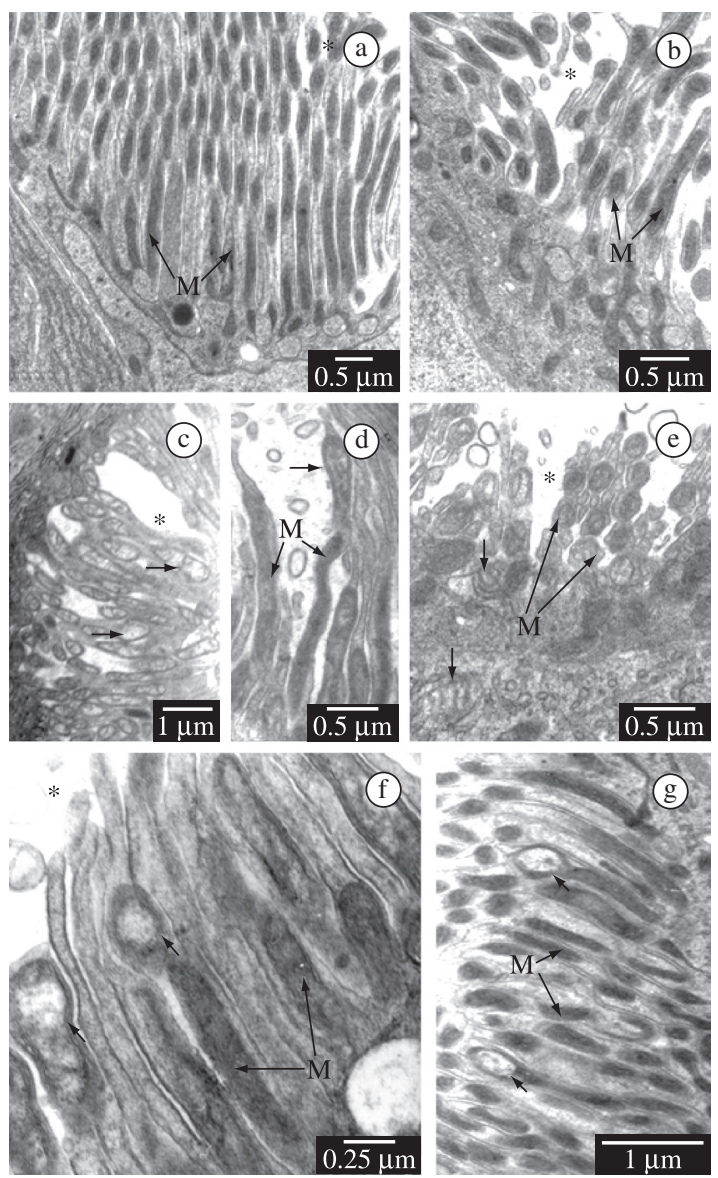

Figure 2. Goblet cell in Diatraea saccharalis non-parasitized larvae (a-b) and parasitized by Cotesia flavipes (c-g). Mitochondria (M); goblet cell cavity (*); a) Anterior region; b) Posterior region; c) Anterior region. Matrix rarefaction (arrow); d) Anterior region. Mitochondrial increase with discrete matrix rarefaction (arrow); e) Anterior region. Matrix rarefaction (arrows); f) Anterior region. Vacuolisation of mitochondrial matrix (arrows); and g) Posterior region. Vacuolisation of mitochondrial matrix (arrows).

the surface of columnar cells (Ferreira et al., 1981; Santos et al., 1984). Many works on peritrophic membrane secretion in Lepidoptera larvae suggest that its constituents are produced by columnar cells, preferentially in the anterior midgut region of insects (Santos et al., 1984).

A previous work on parasitized D. saccharalis showed that the columnar cells present cytoplasmic and nuclear increase in the posterior midgut region of D. saccharalis larvae, due to parasitism, verified by means of morphometry (Pinheiro et al., 2006). Thus the finding of greater mitochondrial alteration in columnar cells of the anterior midgut region indicates that this region is the more affected by parasitism. The increase in cellular volume in the posterior region, concomitant with lesser compromising of mitochondria, suggests that the posterior midgut region must be less compromised by parasitism, and may be recompensing the functioning of the midgut, for the growth and development of the host insect together with its parasitoids.

The goblet cells mitochondria of parasitized D. saccharalis larvae exhibit alterations in both midgut regions, affecting many mitochondria principally in the anterior midgut region. Matrix rarefaction and vacuolisation of the mitochondrial matrix is highly evident in mitochondria present in microvilli of the goblet cell cavity. These microvilli are related to the active transport mechanisms of $\mathrm{K}^{+}$ions from the hemolymph to the intestinal lumen, in cooperation with the adjacent columnar cells (Anderson and Harvey, 1966; Harvey et al. 1983; Moffett et al., 1995; Lehane and Billingsley, 1996; Zeiske et al., 2002). The greater intensity of mitochondrial lesions in the anterior region, due to parasitism, is not reflected in the morphometry of goblet cells (Pinheiro et al., 2006), since there are cytoplasmic and nuclear increases in both midgut regions of $D$. saccharalis parasitized larvae.

Parasitism of $D$. saccharalis larvae affects the mitochondria of regenerative cells that increase in quantity in the anterior and posterior midgut regions; furthermore, those of the anterior region appear to be more affected, with evident ultrastructural alterations. Previous morphometric works show that these cells did not suffer alteration in cytoplasmic or nuclear volume during the parasitism process, in both midgut regions (Pinheiro et al., 2006), which was attributed to the high variability in the morphology of these cells, existent even in non-parasitized larvae (Pinheiro et al., 2003). This variability of regenerative cells must be related to their function along the midgut; it is known that these cells may be differentiated in other epithelial cell types, presenting a high index of morphological variability (Lehane and Billingsley, 1996; Illa-Bochaca and Montuenga, 2006). However, as parasitism in $D$. saccharalis larvae did not bring an increase in cellular death of epithelial cells in the host insect midgut (unpublished data), the cellular reposition resultant from apoptosis is not necessarily altered by parasitism. The mitochondrial alterations had been described in the process of programmed cell death (for review see Leist and Jäättelä, 2001; Brás et al., 2005). The programmed cell death in D. saccharalis midgut has been studied and it could not be correlated only with this mitochondrial alteration (unpublished data).

Nevertheless, the endocrine cells do not present ultrastructural morphological alteration evident in their mitochondria as a consequence of parasitism, except by discrete matrix rarefaction in cells of the anterior midgut region, although there is variability in the mitochondrial morphology of these cells, even in non-parasitized larvae. Few works show the morphology of endocrine cells, but some of them present different endocrine cell types along the insect midgut, with regard to the form, localisation and 

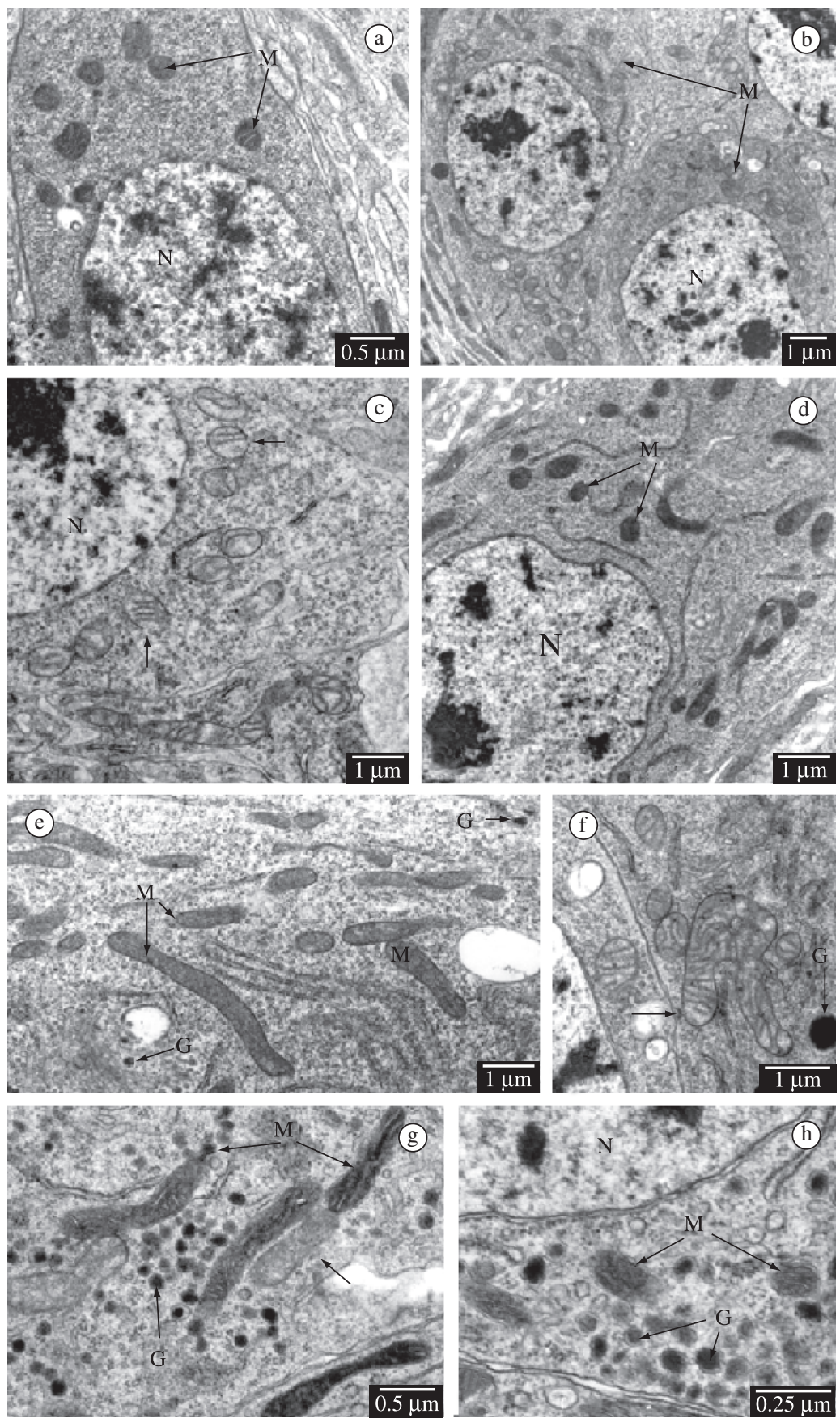

Figure 3. Regenerative and endocrine cells in larvae of Diatraea saccharalis, non-parasitized and parasitized by Cotesia flavipes. Mitochondria (M); Nucleus (N); granules (G). Matrix rarefaction (arrow); a) Regenerative cell, anterior region non-parasitized larvae; b) Regenerative cell, anterior region - parasitized larvae; c) Regenerative cell, anterior region - parasitized larvae; d) Regenerative cell, posterior region - parasitized larvae; e) Endocrine cell, anterior region - non-parasitized larvae; f) Endocrine cell, anterior region - parasitized larvae; g) Endocrine cell, anterior region - parasitized larvae; and h) Endocrine cell, posterior region - parasitized larvae.

morphology, besides electron-density of granules. In this manner ten types were described in Aeshna cyanea (Müller, 1764) (Odonata, Anisoptera) (Andries, 1976), six types in Periplaneta americana (Linnaeus, 1758) (Dictyoptera, Blattidae) (Nishiitsutsuji-Uwo and Endo, 1981) and two types in Melipona quadrifasciata anthidioides Lepeletier, 1836 (Hymenoptera, Apidae) (Neves et al., 2003). The variability of mitochondria observed in cells visualised along the midgut of $D$. saccharalis larvae may be related to the pres- 
Table 1. Ultrastructural characteristics of mitochondria of different midgut epithelial cells in Diatraea saccharalis larvae parasitized and non-parasitized by Cotesia flavipes.

\begin{tabular}{|c|c|c|c|c|c|}
\hline \multirow{3}{*}{$\begin{array}{c}\text { Cytoplasmic } \\
\text { region }\end{array}$} & \multirow[t]{3}{*}{ Characteristic } & \multicolumn{4}{|c|}{ Type of larvae/ Midgut region } \\
\hline & & \multicolumn{2}{|c|}{ Non-Parasitized } & \multicolumn{2}{|c|}{ Parasitized } \\
\hline & & Anterior & Posterior & Anterior & Posterior \\
\hline \multicolumn{6}{|c|}{ Columnar cells } \\
\hline \multirow[t]{5}{*}{ Apical } & Occurrence & + & ++ & +++ & +++ \\
\hline & Quantity of cristae & +++ & +++ & + & ++ \\
\hline & Electron density & +++ & +++ & + & ++ \\
\hline & Matrix Rarefaction & - & - & + & - \\
\hline & Vacuolisation & - & - & + & - \\
\hline \multirow[t]{5}{*}{ Basolateral } & Occurrence & ++ & + & +++ & +++ \\
\hline & Quantity of cristae & +++ & +++ & ++ & ++ \\
\hline & Electron density & +++ & +++ & ++ & ++ \\
\hline & Matrix Rarefaction & - & - & + & - \\
\hline & Vacuolisation & - & - & + & - \\
\hline \multicolumn{6}{|c|}{ Goblet cells } \\
\hline \multirow[t]{5}{*}{ Apical } & Occurrence & + & + & + & + \\
\hline & Quantity of cristae & ++ & ++ & + & + \\
\hline & Electron density & ++ & ++ & + & + \\
\hline & Matrix Rarefaction & - & - & - & - \\
\hline & Vacuolisation & - & - & - & - \\
\hline \multirow[t]{5}{*}{ Basolateral } & Occurrence & ++ & ++ & ++ & ++ \\
\hline & Quantity of cristae & ++ & ++ & + & + \\
\hline & Electron density & ++ & ++ & + & + \\
\hline & Matrix Rarefaction & - & - & ++ & + \\
\hline & Vacuolisation & - & - & ++ & + \\
\hline \multicolumn{6}{|c|}{ Regenerative cells } \\
\hline & Occurrence & + & + & ++ & ++ \\
\hline & Quantity of cristae & ++ & ++ & + & ++ \\
\hline & Electron density & ++ & ++ & + & ++ \\
\hline & Matrix Rarefaction & - & - & + & - \\
\hline & Vacuolisation & - & - & + & - \\
\hline \multicolumn{6}{|c|}{ Endocrine cells } \\
\hline & Occurrence & ++ & ++ & ++ & ++ \\
\hline & Quantity of cristae & variable & ++ & variable & ++ \\
\hline & Matrix density & variable & ++ & variable & ++ \\
\hline & Matrix Rarefaction & - & - & + & - \\
\hline & Vacuolisation & - & - & - & - \\
\hline
\end{tabular}

*Representation of graduated intensity of the presence $(+)$ or absence $(-)$ of ultrastructural characteristic analysed for mitochondria.

ence of different endocrine cell types that could not be identified due to a reduced number of these cells in midgut epithelium, as already described in other species of insects (Montuenga et al., 1989).

It is known that parasitized larvae of Lepidoptera consume less nutrients than the non-parasitized larvae (Thompson and Redak, 2005; Thompson et al., 2005); in this context the mitochondrial modifications detected may reflect a physiological adjustment for nutritional assimilation and digestion of the food ingested since the host need the nutrients to guarantee its own survival and for the parasite growth during the process.

Acknowledgements - We are grateful to the Entomological Laboratory of Usina Barra Grande, Lençóis Paulista-SP, Brazil, for rearing the insects and to Ms. M. H. Moreno and Ms. C. S. Tardivo for the excellent technical assistance. This work was partially supported by FAPESP (Proc. 03/05690-3). 


\section{References}

ANDERSON, E. and HARVEY, WR., 1966. Active transport by the Cecropia midgut: II fine structure of the midgut epithelium. Journal of Cell Biology, vol. 31, no. 1, p. 107-134.

ANDRIES, JC., 1976. Presence de deux types cellulaires endocrines et d'un type exocrine au sein du mesenteron de la larve d'Aeshna cyanea Müller (Odonata: Aeshnidae). International Journal of Insect Morphology and Embryology, vol. 5, no. 6, p. 393-407.

BAKER, JE., WOO, SM. and BYRD, RV., 1984. Ultrastructural features of the gut of Sitophilus granarius (L.) (Coleoptera: Curculionidae) with notes on distribution of proteinases and amylases in crop and midgut. Canadian Journal of Zoology, vol. 62, no. 7, p. 1251-1259.

BRÁS, M., QUEENAN, B. and SUSIN, SA., 2005. Programmed cell death via mitochondria: different modes of dying. Biochemistry, vol. 70 , no. 2 , p. $284-293$.

CLARK, TM., HUTCHINSON, MJ., HUEGEL, KL., MOFFETT, SB. and MOFFETT, DF., 2005. Additional morphological and physiological heterogeneity within the midgut of larval Aedes aegypti (Diptera: Culicidae) revealed by histology, electrophysiology, and effects of Bacillus thuringiensis endotoxin. Tissue and Cell, vol. 37, no. 6 , p. $457-468$.

EDWARDS, JP. and WEAVER, RJ., 2001. Endocrine interactions of insect parasites and pathogens. Trowbridge: The Cromwell Press. 314 p.

FERREIRA, C., BELLINELLO, GL., RIBEIRO, AF. and TERRA, WR., 1990. Digestive enzymes associated with the glycocalyx, microvillar membranes and secretory vesicles from midgut cells of Tenebrio molitor larvae. Insect Biochemistry, vol. 20, no. 8, p. $839-847$.

FERREIRA, C., RIBEIRO, AF. and TERRA, WR., 1981. Fine structure of the larval midgut of the fly Rhynchosciara and its physiological implications. Journal of Insect Physiology, vol. 27, no. 8, p. 559-570.

HARVEY, WR., CIOFFI, M., DOW, JAT. and WOLFERSBERGER, MG., 1983. Potassium ion transport ATPase in insect epithelia. The Journal of Experimental Biology, vol. 106, no. 1, p. 91-117.

HUNG, CN., LIN, TL. and LEE, WY., 2000. Morphology and ultrastructure of the alimentary canal of the oriental fruit fly, Bactrocera dorsalis (Hendel) (Diptera: Tephritidae) (2): the structure of the midgut. Zoological Studies, vol. 39, no. 4, p. 387-394.

ILLA-BOCHACA, I. and MONTUENGA, LM., 2006. The regenerative nidi of the locust midgut as a model to study epithelial cell differentiation from stem cells. The Journal of Experimental Biology, vol. 209, no. 11, p. 2215-2223.

JORDÃO, BP., CAPELLA, AN., TERRA, WR., RIBEIRO, AF. and FERREIRA, C., 1999. Nature of the anchors of membranebound aminopeptidase, amylase, trypsin a secretory mechanism in Spodoptera frugiperda (Lepidoptera) midgut cells. Journal of Insect Physiology, vol. 45, no. 1, p. 29-37.

LEHANE, MJ. and BILLINGSLEY, PF., 1996. Biology of the insect midgut. London: Chapman and Hall. 486 p.

LEIST, M. and JÄÄTTELÄ, M., 2001. Four deaths and a funeral: from caspases to alternative mechanisms. Nature Reviews Molecular Cell Biology, vol. 2, no. 8, p. 589-598.

LEVY, SM., FALLEIROS, AMF., GREGÓRIO, EA., ARREBOLA, NR. and TOLEDO, LA., 2004. The larval midgut of Anticarsia gemmatalis (Hübner) (Lepidoptera: Noctuidae): light and electron microscopy studies of the epithelial cells. Revista Brasileira de Biologia $=$ Brazilian Journal of Biology, vol. 64, no. 3, p. 1-8.
MANDEL, LJ., MOFFETT, DF., RIDDLE, TG. and GRAFTON, MM., 1980. Coupling between oxidative metabolism and active transport in the midgut of tobacco hornworm. American Journal of Physiology, vol. 238, no. 1, p. 1-9.

MOFFETT, DF., KOCH, A. and WOODS, R., 1995. Electrophysiology of $\mathrm{K}^{+}$transport by epithelium of lepidopteran insect larvae. III Goblet valve patency. The Journal of Experimental Biology, vol. 198, no. 10, p. 2103-2113.

MONTUENGA, LM., BARRENECHEA, MA., SESMA, P., LÓPEZ, J. and VASQUES, JJ., 1989. Ultrastructure and immunocytochemistry of endocrine cells in the midgut of the desert locust, Schistocerca gregaria. Cell and Tissue Research, vol. 258, no. 3, p. 577-583.

NEVES, CA., SERRÃO, JE. and GITIRANA, LB., 2003. Ultrastructure of midgut endocrine cells in Melipona quadrifasciata anthidioides (Hymenoptera, Apidae). Revista Brasileira de Biologia = Brazilian Journal of Biology, vol. 63, no. 4, p. 683-690.

NISHIITSUTSUJI-UWO, J. and ENDO, Y., 1981. Gut endocrine cells in insects: The ultrastructure of the endocrine cells in the cockroach midgut. Biomedical Research, vol. 2, no. 1, p. 30-44.

PINHEIRO, DO., CONTE, H. and GREGÓRIO, EA., 2008 a. Spherites in the midgut epithelial cells of the sugarcane borer parasitized by Cotesia flavipes. Biocell, vol. 32, no. 1, p. 61-67.

PINHEIRO, DO., QUAGIO-GRASSIOTTO, I. and GREGÓRIO, EA., 2008b. Morphological regional differences of epithelial cells along of the midgut in Diatraea saccharalis Fabricius (Lepidoptera: Crambidae) larvae. Neotropical Entomology, vol. 37, no. 4, p. 403-419.

PINHEIRO, DO. and GREGÓRIO, EA., 2003. Ultrastructure of the columnar epithelial cell along the midgut of the Diatraea saccharalis (Lepidoptera: Pyralidae) larvae. Acta Microscópica, vol. 12 , no. 1 , p. $27-30$.

PINHEIRO, DO., SILVA, RJ. and GREGÓRIO, EA., 2006. Morphometry of the Diatraea saccharalis Fabricius, 1794 (Lepidoptera) midgut epithelium parasitized by the wasp Cotesia flavipes Cameron, 1891 (Hymenoptera). Journal of Invertebrate Pathology, vol. 93, no. 1, p. 60-62.

PINHEIRO, DO., SILVA, RJ., QUAGIO-GRASSIOTTO, I. and GREGÓRIO, EA., 2003. Morphometric study of the midgut epithelium in the Diatraea saccharalis Fabricius (Lepidoptera: Pyralidae) larvae. Neotropical Entomology, vol. 32, no. 3, p. 453-459.

SANTOS, CD., RIBEIRO, AF., FERREIRA, C. and TERRA, WR., 1984. The larval midgut of the cassava hornworm (Erinnyis ello). Ultrastructure, fluid fluxes, the secretory activity in relation to the organization of digestion. Cell and Tissue Research, vol. 237, no. 3, p. $565-574$.

SERRÃO, JE. and CRUZ-LANDIM, C., 2000. Ultrastructure of the midgut epithelium of Meliponinae larvae with different developmental stages and diets. Journal of Apicultural Research, vol. 39 , no. 1-2, p. 9-17.

THOMPSON, SN. and REDAK, RA., 2005. Feeding behaviour and nutrient selection in an insect Manduca sexta $\mathrm{L}$. and alterations induced by parasitism. Journal of Comparative Physiology-A, vol. 191, no. 10, p. 909-923.

THOMPSON, SN., REDAK, RA. and WANG, LW., 2005. Nutrition interacts with parasitism to influence growth and physiology of the insect Manduca sexta L. The Journal of Experimental Biology, vol. 208, no. 4, p. 611-623.

ZEISKE, W., MEYER, H. and WIECZORECK, H., 2002. Insect midgut $\mathrm{K}^{+}$secretion: concerted run-down of apical/basolateral transporters with extra/intracellular acidity. The Journal of Experimental Biology, vol. 205, no. 4, p. 463-467. 